\title{
Semen and haematological responses of rabbit bucks administered oral folic acid
}

\author{
Wisdom Amaduruonye ${ }^{1^{*}}$, Joshua Nathaniel ${ }^{1}$, Christopher Agboje Agida ${ }^{2}$, Yakubu lbrahim ${ }^{3}$, \\ Chidinma A. Ndukauba ${ }^{1}$ and Udo Herbert ${ }^{1}$
}

\begin{abstract}
1Department of Animal Breeding and Physiology, Michael Okpara University of Agriculture, Umudike, Abia State, Nigeria. ${ }^{2}$ Department of Animal Nutrition and Forage Science, Michael Okpara University of Agriculture, Umudike, Abia State, Nigeria. ${ }^{3}$ Department of Animal Science, Federal University Kashere, Gombe State, Nigeria.

*Corresponding author: amaduruonye.wisdom@mouau.edu.ng; amaduruonyewisdomjw@gmail.com
\end{abstract}

Copyright $@ 2021$ Amaduruonye et al. This article remains permanently open access under the terms of the Creative Commons Attribution License $\underline{4.0}$, which permits unrestricted use, distribution, and reproduction in any medium, provided the original work is properly cited.

Received 12th November, 2020; Accepted 8th December, 2020

\begin{abstract}
Some researchers have inferred that folic acid is necessary for reproduction and could enhance blood formation. Thus, a Completely Randomized Design Experiment (CRD) was conducted to evaluate the impact of oral administration of folic acid on the semen and haematological characteristics of New Zealand White rabbit bucks. The treatments designated treatment $1\left(T_{1}\right)$, treatment $2\left(T_{2}\right)$ and treatment $3\left(T_{3}\right)$ having 12 rabbits each were replicated 3 times with 4 rabbits per replicate. The ages of the 36 pre-pubertal rabbit bucks were between 2 to 3 months, and weighed approximately $2.56 \mathrm{~kg}$. Three experimental diets were formulated to meet the nutrient requirements of rabbit bucks. Each rabbit buck on $T_{1}$ were orally administered folic acid at $0.0 \mathrm{mg}, \mathrm{T}_{2} 2.5 \mathrm{mg}$ folic acid and $\mathrm{T}_{3} 5.0 \mathrm{mg}$ folic, respectively. Data were collected for semen characteristics and haematology from the rabbit bucks. Data collected on different parameters were subjected to analysis of variance (ANOVA). Results showed that significant increases $(p<0.05)$ were observed on libido, semen $\mathrm{pH}$, spermatozoa progressive motility (67.40-80.20\%), spermatozoa live proportion (83.01-94.12\%), sperm concentration $(112.24-133.80 \times 10 \% / \mathrm{ml})$, total number of sperm per ejaculate $\left(50.65-67.66 \times 10^{6} / \mathrm{ml}\right)$, total viable sperm $(291.58-496.69 \times 10 \% / \mathrm{ml})$, normal sperm proportion $(85.16-91.64 \%)$. Also, significant reductions $(\mathrm{p}<0.05)$ were observed on the percentage head abnormality of the spermatozoa (3.74-3.18), total abnormality (2.13-0.93), mid-piece abnormality (2.35-0.79), cytoplasmic abnormality (7.17-2.89), and total abnormality (14.84-8.35); while the haematological parameters such as haemoglobin (13.53-14.20 g/dl), packed cell volume $(33.00-34.96 \%)$, white blood cell $\left(6.81-7.80 \times 10^{3} \mathrm{~mm}^{3}\right)$ and the differential white blood cells improved significantly $(p<0.05)$ following the oral administration of folic acids to the rabbit bucks. Thus, the oral administrations of folic acid at $5.0 \mathrm{mg}$ per rabbit buck most significantly improved the semen characteristics, enhanced the overall spermatozoa morphology, reduced sperm cells abnormalities and also improved some haematological parameters of the rabbit bucks.
\end{abstract}

Keywords: Folic acid, haematology, immuno-modulatory, semen, rabbit bucks.

\section{INTRODUCTION}

In the face of the rising unemployment, many Nigerians have ventured into animal agriculture as an anchor for sustainable economy, human development and as a means of employment. As such, it has become imperative to enhance animal physiology and production potentials of farm animals so as to sustain the present interest of those venturing into animal agriculture. One of the primary purposes of animal agriculture is reproduction. Semen characteristics and blood profile is very essential for effective reproduction in rabbits. Reproductive failure has been a major source of economic loss in animal agriculture. Poor physiological conditions and malnutrition has contributed to the decline in reproductive performance of farm animals (Frandson et al., 2000; Lotti and Maggi, 2015; Onunkwo et al., 2018; Uchewa et al., 2018). Inefficient reproductive system, poor management, and 
decline in blood profiles and poor semen constituents have contributed to this failure (Brugh and Lipshultz, 2004; Barratt, 2007; Fisch, 2008; Butt and Akram, 2013; Amaduruonye et al., 2018). The general physiology of rabbits have been reported to be largely affected by several factors such as nutrition, drugs, hormones, environmental and other physiological factors (Addass et al., 2012; Sabra and Al-Harbi, 2014; Amaduruonye, et al., 2017).

Folic acid (Vitamin B-9) is a water soluble vitamin belonging to the group of vitamin $\mathrm{B}$ complexes. Folic acid (Folacin) is converted into folate by the body and used as a dietary supplement. Folic acid helps the cells to build and maintain new cells; and also help to prevent changes in the DNA that may lead to cancer. Folic acid is used to treat and correct folic acid deficiency and certain other types of anemia (Foster et al., 2009; Baykan et al., 2011). On reproduction, folic acid helps to prevent major birth defects, such as the defects of the Central Nervous System (CNS) and the spines of the developing fetus (Czeizel, 2000; Coll et al., 2004; Unusan, 2004; Nawapun and Phupong, 2007). Folic acid increases sperm production in men, boosts fertility in males and females, and could be used as a fertility supplements for males and females (Morin et al., 2002; Ajrouche et al., 2014; Hodgetts et al., 2015). Folic acid is an antioxidant, anti-aging and moisturizing, helping to maintain the skin natural beauty (Josh et al., 2001, Debowska et al., 2005).

The retardation of male reproductive performance is one of the major indicators of reduction in reproductive capacity in farm animals. To solve these problems, efforts should be geared toward enhancing the efficacy of rabbit reproduction through improvements in semen and blood profile. Therefore, there is a need to improve the overall physiology of rabbit bucks so as to enhance rabbit reproduction. This study was aimed to examine the impact of oral administration of folic acid on semen and haematological characteristics of rabbit bucks.

\section{MATERIALS AND METHODS}

This research was conducted in the Rabbitry Unit of the Teaching and Research Farm of the College of Animal Science and Animal Production, Michael Okpara University of Agriculture, Umudike, Abia State, Nigeria. Umudike is located in Abia State, Nigeria. The location is situated at latitude $05^{\circ} 29^{1}$ North and longitude $07^{\circ} 31^{1}$ East; and at an altitude of 122 meters above sea level (NRCRI, 2004). It lies within the tropical rainforest zone of South Eastern Nigeria. The location is characterized by average annual rainfall of $2,177 \mathrm{~mm}$ in 148 to 155 rain days (NRCRI, 2004). The average ambient temperature is $25.5^{\circ} \mathrm{C}$ with minimum and maximum temperature of 22 and $29^{\circ} \mathrm{C}$, respectively. Relative humidity ranged from 57 to $91 \%$. The metrological data were collected from the Meteorological Center of National Root Crop Research
Institute, Umudike, Abia State (NRCRI, 2004).

Thirty-six (36) pre-pubertal New Zealand white rabbit bucks aged 2 to 3 months sourced from the Teaching and Research farm of the College of Animal Science and Animal Production, Michael Okpara University of Agriculture, Umudike, were used for the study. A quarantine period of 2 weeks pre- experimental period was allowed during which the animals were vaccinated against ecto and endo-parasite using Ivomectin and Levamisole $(0.1 \mathrm{ml} / \mathrm{kg}$ body weight), respectively. The experimental animals were housed singly in pens of colony hutches for ease of identification throughout the experimental period. They were fed the experimental diet and administered oral folic acid. Feed and clean drinking water were provided ad libitum. Routine management practices were also carried out appropriately. The compositions of the experimental diets are presented in Table 1.

\section{Experimental design}

The study was a Completely Randomized Design (CRD) trial with three treatments consisting of $T_{1}, T_{2}$, and $T_{3}$. The $\mathrm{T}_{1}$ served as the control. Twelve (12) rabbit bucks were randomly assigned to each treatment, balanced for weights and replicated 3 times, with 4 rabbits per replicate. The Folic acid were administered orally to the rabbit bucks between 7.00 and 8.00 am Nigeria local time after feeding, on each day of administration at two days interval throughout the experimental period. The folic acid was dissolved in $5 \mathrm{ml}$ of water and drenched orally to the rabbit bucks using a $10 \mathrm{ml}$ string on each day of administration to ensure efficient and uniform consumption. Each rabbit buck on $T_{1}$ were orally administered folic acid at $0.0 \mathrm{mg}$, $\mathrm{T}_{2} 2.5 \mathrm{mg}$ folic acid and $\mathrm{T}_{3} 5.0 \mathrm{mg}$ folic acid, respectively. The field work lasted for 16 weeks. The experimental model is as follows:

$Y_{i j}=U+T_{i}+e_{i j}$

Where: $Y=$ individual observation on the rabbit characteristics; $\mu=$ overall mean; $T_{i}=$ treatment effect; $e_{i j}$ = random error assumed to be independently, identically and normally distributed with zero means and constant variances.

\section{Data collection and evaluation}

A matured doe (teaser) was introduced to the buck prior to semen collection to monitor their sex drive. The time in seconds it took for the rabbit bucks to sniff, groom and mount the female was recorded with a stop watch. Libido (reaction time) were determined by observing the time taken (seconds) from exposure of the buck to the doe and the first copulation as recommended by Herbert and Acha (1995). 
Table 1. Feed composition and calculated nutrients of experimental diets.

\begin{tabular}{lc}
\hline Ingredients & $\begin{array}{c}\text { Percentage } \\
\text { composition }\end{array}$ \\
\hline Maize & 44.94 \\
Soya beans & 17.31 \\
Rice husk & 32.00 \\
Fishmeal & 2.00 \\
Bone meal & 1.00 \\
Limestone & 2.00 \\
Vit/min Premix* & 0.25 \\
Salt & 0.50 \\
Total & 100.00 \\
& \\
Calculated nutrients & \\
Crude Protein (\%) & 17.00 \\
Metabolizable Energy (ME) (Kcal/kg diet) & 2505.42 \\
Crude fiber (\%) & 11.36 \\
Lysine (\%) & 0.514 \\
Methionine (\%) & 0.199 \\
\hline
\end{tabular}

*Premix composition (per $\mathrm{kg}$ of diet): vitamin A, 12,500 IU; vitamin D3, $2500 \mathrm{IU}$; vitamin $\mathrm{E}, 50.00 \mathrm{mg}$; vitamin $\mathrm{K} 3,2.50 \mathrm{mg}$; vitamin $\mathrm{B} 1,3.00 \mathrm{mg}$; vitamin B2, $6.00 \mathrm{mg}$; vitamin B6, 6.00mg; niacin, $40 \mathrm{mg}$; calcium pantothenate, $10 \mathrm{mg}$; biotin, $0.08 \mathrm{mg}$; vitamin $\mathrm{B} 12,0.25 \mathrm{mg}$; folic acid, $1.00 \mathrm{mg}$; chlorine chloride, $300 \mathrm{mg}$; manganese, $100 \mathrm{mg}$; iron, $50 \mathrm{mg}$; zinc, $45 \mathrm{mg}$; copper, $2.00 \mathrm{mg}$; iodine, $1.55 \mathrm{mg}$; cobalt, $0.25 \mathrm{mg}$; selenium, $0.10 \mathrm{mg}$; antioxidant, $200 \mathrm{mg}$.

During semen collection, Artificial Vagina (AV) with a calibrated glass collection tube constructed by Herbert and Adejumo (1995) was used for semen collection. Two weeks prior to semen collection, the bucks were trained to serve an artificial vagina using a teaser rabbit doe. The semen was collected between 9.00 am and 10.00 am local Nigeria time on the day of semen collection. During semen collection, the rabbit doe was taken to the buck's cage and held in position for service. The AV was lubricated using glycerol and its temperature adjusted to 36 to $40^{\circ} \mathrm{C}$. The artificial vagina was strategically placed under the belly of the doe such that the penis of the buck was introduced into the artificial vagina.

\section{Estimation of semen characteristics}

Semen evaluation involved the estimation of both the macroscopic and microscopic indices. Semen volume was determined in milliliter directly from the calibrated glass collection tube attached to the Artificial Vagina (AV). Semen $\mathrm{pH}$ was determined using a $\mathrm{pH}$ meter. Semen color and consistency were determined subjectively using the scoring pattern as described by Chibundu (2005). Spermatozoa concentration was determined using a haemocytometer as described by Jequier, (2010). The total number of spermatozoa was determined by multiplying semen volume by the spermatozoa concentration.
Sperm motility was determined subjectively with a drop of fresh semen on a glass slide covered with slip and examined using a microscope as described by Oguike et al. (2019). Sperm morphology was determined by performing differential counts of the morphologically normal and abnormal structures of the spermatozoa using eosin-nigrosin stain. Spermatozoa live proportion, total number of spermatozoa per ejaculate, percentage relative gel formation and relative clumping of spermatozoa were determined using the methods of Brazil (2010).

\section{Haematology}

Blood samples for hematological examination were collected from the rabbit bucks. A $5 \mathrm{ml}$ syringe fitted with a sterile needle was used to collect $2 \mathrm{ml}$ of blood and quickly transferred to ethylene diamine tetraacetic acid (EDTA) sample bottles. The EDTA sample bottles were shaken gently to prevent clotting. The following hematological indices were determined: hemoglobin, packed cell volume, red blood cell, white blood cell and its differentials, mean cell volume, mean cell hemoglobin and mean cell hemoglobin concentration. The packed cell volume (PCV) was determined by the micro-hematocrit method as described by Kahn et al. (2010). Haemoglobin $(\mathrm{Hb})$ concentration was determined using a spectrophotometer through the cyanomethaemoglobin method as described by Putwain (2008). Red blood cell (RBC), white blood cell (WBC) counts and its 'differentials' were determined using Neubauer hemocytometer method as described by Feldman et al. (2000). Mean corpuscular volume (MCV), mean corpuscular hemoglobin $(\mathrm{MCH})$ and mean corpuscular hemoglobin concentration $(\mathrm{MCHC})$ were calculated according to Bain (2006).

\section{Statistical analysis}

Data collected on different parameters were subjected to analysis of variance (ANOVA) in accordance with the methods of Steel and Torie (1980). Significance means were separated according to Duncan's Multiple Range Test (Duncan, 1955).

\section{RESULTS AND DISCUSSION}

The semen characteristics of rabbit bucks on oral administration of folic acid is presented in Table 2. From the results in Table 2, no significant differences $(p>0.05)$ were observed on the semen volume, semen color and spermatozoa motility on the oral administration of folic acid to the rabbit bucks. They are statistically similar with the control group. Furthermore, significant improvements $(p<0.05)$ were observed on the libido, semen $\mathrm{pH}$, semen consistency, spermatozoa progressive motility, spermatozoa live proportion, semen concentration, total number of spermatozoa per ejaculate, total viable spermatozoa and 
Table 2. Semen characteristics of rabbit bucks on oral administration of folic acid.

\begin{tabular}{|c|c|c|c|c|}
\hline Parameter & $\mathbf{T}_{1}$ & $\mathbf{T}_{2}$ & $\mathbf{T}_{3}$ & SEM \\
\hline Libido/Reaction time (sec.) & $12.82^{\mathrm{a}}$ & $10.47^{b}$ & $9.00^{b}$ & 1.12 \\
\hline Semen volume $(\mathrm{ml})$ & 0.45 & 0.45 & 0.50 & 0.08 \\
\hline Semen color (1-2) & 1.00 & 1.00 & 2.00 & 0.23 \\
\hline Semen consistency (1-4) & $2.00^{b}$ & $3.20^{a}$ & $3.66^{a}$ & 0.45 \\
\hline Semen $\mathrm{pH}(1-14)$ & $7.47^{a}$ & $6.89^{b}$ & $6.70^{\mathrm{b}}$ & 0.54 \\
\hline Spermatozoa motility (1-4) & 3.00 & 3.00 & 3.00 & 0.05 \\
\hline Spermatozoa progressive motility (\%) & $67.40^{\mathrm{c}}$ & $74.65^{\mathrm{b}}$ & $80.20^{a}$ & 2.41 \\
\hline Spermatozoa live proportion (\%) & $83.01^{\mathrm{c}}$ & $88.60^{\mathrm{b}}$ & $94.12^{\mathrm{a}}$ & 1.33 \\
\hline Spermatozoa concentration $\left(\times 10^{6} / \mathrm{ml}\right)$ & $112.24^{c}$ & $125.78^{b}$ & $133.80^{\mathrm{a}}$ & 2.54 \\
\hline Total number spermatozoa per ejaculate $\left(\times 10^{6} / \mathrm{ml}\right)$ & $50.65^{\mathrm{b}}$ & $56.66^{\mathrm{ab}}$ & $67.66^{\mathrm{a}}$ & 2.13 \\
\hline Total viable spermatozoa $\left(\times 10^{9} / \mathrm{ml}\right)$ & $291.58^{c}$ & $381.39^{b}$ & $496.69^{a}$ & 10.98 \\
\hline Normal spermatozoa proportion (\%) & $85.16^{\mathrm{b}}$ & $90.02^{\mathrm{a}}$ & $91.64^{\mathrm{a}}$ & 1.07 \\
\hline
\end{tabular}

abc: Means with different superscripts along rows are significantly different $(p<0.05)$. SEM= Standard error of means.

normal spermatozoa proportion on the oral administration of folic acid on the rabbit bucks. The oral administration of the folic acid might have stimulated the secretion of testosterone for spermatogenesis which increases the libido of the rabbit bucks and reduced the reaction time. The semen volume and semen concentration observed on this study agrees with the findings of Herbert and Acha (1995) and Ekuma et al. (2017) who reported that rabbit semen volume ranges between 0.4 to $0.71 \mathrm{ml}$ and semen concentration range of 50 to $350 \times 10^{6} / \mathrm{mm}^{3}$, respectively.

The $\mathrm{pH}$ of the collected semen sample ranges between 7.47 in $T_{1}$ and 6.70 in $T_{3}$. The decrease on semen $\mathrm{pH}$ as observed in this study were as a result of increase in spermatozoa concentration of the collected semen, increase on the total number of spermatozoa per ejaculate and as well as the increase in spermatozoa metabolic activity as the level of administration of the folic acid increased from 2.5 to $5.0 \mathrm{mg}$; which in turn increased the rate of fructolysis and fructolytic index of the collected semen. Fructolysis index is the rate of fructose utilization in a semen sample by spermatozoa in one hour at $37^{\circ} \mathrm{C}$ for their metabolic activities (Harvey and Ferrier, 2011; Sun and Empie, 2012; Sabra and Al-Harbi, 2014). The rate of fructolysis is higher in good quality semen. The higher the semen concentration, the higher the metabolic activities in the semen sample, the more fructose utilization in a given semen sample. Semen quality can be assessed by measuring the rate of fructose utilization and fructolytic index in a semen sample. Fructose utilization by sperm cells produced lactic acid in the semen, which in turn increased the semen pH (Molina et al., 2010; Misro and Ramya, 2012; Toragall, et al., 2019). Therefore, increased in semen concentration and increased in sperm cell number as observed in Table 2 increased the rate of metabolic activity in the collected semen, increased the accumulation of lactic acid in the semen, and also increased the fructolysis index; thereby increasing the $\mathrm{pH}$ of the collected semen sample. Moreover, the tail and mid piece of a spermatozoa are responsible for spermatozoa motility (Björndahl, 2010; Mukhopadhyay et al., 2010; Naina and Sing, 2015; Meri and Anu, 2017). Therefore, the significantly improvements $(p<0.05)$ observed on the Spermatozoa progressive motility is attributable to the significant reduction in the clumping of the spermatozoa, reduction on the tail and mid-piece abnormalities of the rabbit bucks administered oral folic acid (Table 3). The lower the tail and mid-piece abnormalities, the higher the spermatozoa progressive motility. Also, the significant improvement on the spermatozoa live proportion, total viable spermatozoa and normal spermatozoa proportion is attributed to the significant reduction on the total abnormalities and cytoplasmic abnormalities of the sperm cells in the semen sample collected from the rabbit bucks administered oral folic acid (Table 3). From these observations, it could be inferred that the oral administration of folic acid at 2.5 and $5.0 \mathrm{mg}$ improved the semen characteristics of the rabbit bucks.

The differential spermatozoa morphology of rabbit bucks on oral administration of folic acid is presented in Table 3. The result of the differential spermatozoa morphology of rabbit bucks showed that significant reductions $(p<0.05)$ were observed on the abnormalities of the head, tail, midpiece, cytoplasmic, total abnormalities, gel formation and clumping of spermatozoa following the oral administration of folic acid at 2.5 and $5.0 \mathrm{mg}$ compared to the control. The significant reduction $(p<0.05)$ observed on the abnormalities of the tail, mid-piece and clumping of the spermatozoa following the oral administration of folic acid must have been responsible for the observed significant increase on the progressive motility of the spermatozoa (Table 2). Abnormalities in spermatozoa structures and morphologies (teratospermia) are sometimes caused or influenced by genetic, nutrition, drugs, age, chemicals, and environmental factors (Brugh and Lipshultz, 2004; Mukhopadhyay et al., 2010; Harris et al., 2011; Naina and Singh, 2015). Also, the significant reductions $(p<0.05)$ 
Table 3. Differential spermatozoa morphology of rabbit bucks on oral administration of folic acid.

\begin{tabular}{lcccc}
\hline Parameter (\%) & $\mathbf{T}_{1}$ & $\mathbf{T}_{2}$ & $\mathbf{T}_{3}$ & SEM \\
\hline Head abnormality & $3.74^{\mathrm{a}}$ & $3.64^{\mathrm{a}}$ & $3.18^{\mathrm{b}}$ & 0.09 \\
Tail abnormality & $2.13^{\mathrm{a}}$ & $1.49^{\mathrm{b}}$ & $0.93^{\mathrm{c}}$ & 0.12 \\
Mid-piece abnormality & $2.35^{\mathrm{a}}$ & $1.98^{\mathrm{a}}$ & $0.79^{\mathrm{b}}$ & 0.34 \\
Cytoplasmic abnormality & $7.17^{\mathrm{a}}$ & $2.86^{\mathrm{b}}$ & $2.89^{\mathrm{b}}$ & 1.26 \\
Total abnormality & $14.84^{\mathrm{a}}$ & $9.98^{\mathrm{b}}$ & $8.35^{\mathrm{c}}$ & 1.32 \\
Relative gel formation & $5.66^{\mathrm{a}}$ & $2.54^{\mathrm{b}}$ & $1.00^{\mathrm{c}}$ & 0.43 \\
Relative clumping of spermatozoa & $4.66^{\mathrm{a}}$ & $2.05^{\mathrm{b}}$ & $1.10^{\mathrm{b}}$ & 0.61 \\
\hline
\end{tabular}

abc: Means with different superscripts along rows are significantly different $(p<0.05)$. SEM= Standard error of means.

Table 4. Haematology of rabbit bucks on oral administration of folic acid.

\begin{tabular}{lcccc}
\hline Parameters & $\mathbf{T}_{1}$ & $\mathbf{T}_{\mathbf{2}}$ & $\mathbf{T}_{\mathbf{3}}$ & $\mathbf{S E M}$ \\
\hline Haemoglobin $(\mathrm{g} / \mathrm{dl})$ & $13.53^{\mathrm{b}}$ & $13.96^{\mathrm{ab}}$ & $14.20^{\mathrm{a}}$ & 0.21 \\
Packed Cell Volume (\%) & $33.00^{\mathrm{b}}$ & $33.66^{\mathrm{b}}$ & $34.96^{\mathrm{a}}$ & 0.31 \\
Red Blood Cell $\left(\times 10^{6} \mathrm{~mm}^{3}\right)$ & 5.41 & 5.62 & 5.76 & 0.32 \\
White Blood Cell $\left(\times 10^{3} \mathrm{~mm}^{3}\right)$ & $6.81^{\mathrm{c}}$ & $7.20^{\mathrm{b}}$ & $7.80^{\mathrm{a}}$ & 0.07 \\
Mean Corpuscular Volume (fl) & 60.99 & 59.86 & 60.84 & 1.34 \\
MCH (pg) & 25.01 & 24.83 & 24.65 & 1.65 \\
MCHC (g/dl) & 13.53 & 13.96 & 14.20 & 1.06 \\
\hline
\end{tabular}

abc: Means with different superscripts along rows are significantly different $(p<0.05)$. SEM= Standard error of means. $M C H=M e a n$ Corpuscular Hemoglobin; $\mathrm{MCHC}=$ Mean Corpuscular Hemoglobin Concentration.

Table 5. Differential white blood cells of rabbit bucks on oral administration of folic acid.

\begin{tabular}{lcccc}
\hline Parameters (\%) & $\mathbf{T}_{1}$ & $\mathbf{T}_{2}$ & $\mathbf{T}_{3}$ & SEM \\
\hline Lymphocyte & $56.00^{\mathrm{c}}$ & $65.00^{\mathrm{a}}$ & $60.00^{\mathrm{b}}$ & 1.20 \\
Neutrophil & $35.00^{\mathrm{a}}$ & $32.00^{\mathrm{b}}$ & $30.00^{\mathrm{c}}$ & 0.80 \\
Monocyte & $6.00^{\mathrm{a}}$ & $5.00^{\mathrm{ab}}$ & $3.66^{\mathrm{b}}$ & 0.76 \\
Eosinophil & $1.00^{\mathrm{c}}$ & $1.66^{\mathrm{b}}$ & $3.00^{\mathrm{a}}$ & 0.02 \\
Basophil & 0.00 & 0.00 & 0.00 & 0.00 \\
\hline
\end{tabular}

abc: Means with different superscripts along rows are significantly different $(p<0.05)$. SEM= Standard error of means.

observed on the cytoplasmic abnormalities and total abnormality must have contributed to the improvements observed on the normal spermatozoa, total spermatozoa and live sperm proportions of the rabbit bucks administered oral folic acid as observed in Table 2. From these observations, it showed that the oral administration of folic acid improved the spermatozoa morphology of the New Zealand rabbit bucks.

The haematology of rabbit bucks on oral administration of folic acid is presented in Table 4 . The results of the haematological analysis of the rabbit bucks showed that red blood cells, mean corpuscular volume, mean corpuscular haemoglobin and mean corpuscular haemoglobin concentrations were not significantly affected. They are statistically similar $(p>0.05)$ with the control group. Furthermore, significant improvements $(p<0.05)$ were observed on the haemoglobin, packed cell volume and white blood cells of the rabbits administered oral folic acid compared to the control group. This showed that folic acid stimulated the production of the red blood cells from the bone marrow, improved the oxygen carrying capacity of the haemoglobin, which could enhanced the muscular activities of the rabbit bucks. Moreover, the haemoglobin concentration, packed cell volume and white blood cell are within the normal range $(10.4-17.4 \mathrm{~g} / \mathrm{dl})$ for haemoglobin, $(25.0-50.0 \%)$ for PCV, and white blood cell $\left(2.71-12.23 \times 10^{3} \mathrm{~mm}^{3}\right)$ as recommendation by Jenkins (2006), Moore et al. (2015) and Leineweber et al. (2018), respectively, for healthy rabbit bucks. These results showed that oral administration of folic acids at 2.5 and 5.0 $\mathrm{mg}$ improved the haemoglobin, packed cell volume and the white blood cells of the rabbit bucks.

The differential white blood cells of rabbit bucks on oral administration of folic acid is presented in Table 5. The 
result of the differential white blood cells showed that there were significant increases $(p<0.05)$ on the lymphocyte and eosinophil, while the neutrophils and monocytes of the rabbit bucks administered folic acid significantly decreased $(p<0.05)$ compared to the rabbit bucks on the control group. The functions of these differential white blood cells were to protect and defend the body against different forms of infections and diseases by stimulating the immune system response on defense against disease infestations (McCarrel et al., 2012; Cross et al., 2015; Riboh et al., 2016; King et al., 2018). The physiological actions impacted by the administered folic acid on the white blood cells and its 'differentials' of the rabbit bucks is an indication that folic acid has the potency to stimulate the immune system response and possessed an immunemodulatory properties.

\section{Conclusion}

Based on the results and observations from this study, it is concluded that oral administration of folic acids at $5.0 \mathrm{mg}$ per rabbit buck most significantly improved the semen characteristics, enhanced the spermatozoa morphology, reduced sperm cell abnormalities and improved some haematological parameters of the rabbit bucks.

\section{Recommendation}

From the results obtained, it is recommend that up to 5.0 $\mathrm{mg}$ of folic acid per rabbit buck could be administered orally to improve the semen quality and some haematological parameters of New Zealand white rabbit bucks.

\section{CONFLICTS OF INTEREST}

The authors declare that they have no conflict of interest.

\section{ACKNOWLEDGEMENT}

The authors are indebted to the Vice chancellor of Michael Okpara University of Agriculture Umudike, Abia State, Nigeria and the Head of the Department of Animal Breeding and Physiology, for allowing us to use the University facilities for this research. We appreciate the farm and laboratory staff of the College of Animal Science and Animal Production for their support during the period of this research.

\section{REFERENCE}

Addass, P. A., David, D. L., Edward, A., Zira, K. E., \& Midau, A. (2012). Effect of age, sex and management system on some haematological parameters of intensively and semi-intensively kept chicken in Mubi, Adamawa State, Nigeria. Iranian Journal of Applied Animal Science, 2(3), 277-282.
Ajrouche, R., Rudant, J., Orsi, L., Petit, A., Baruchel, A., \& Nelken, B., (2014). Maternal reproductive history, fertility treatments and folic acid supplementation in the risk of childhood acute leukemia: the ESTELLE study. Cancer Causes Control, 25, 1283-1293.

Amaduruonye, W., Ekuma, B. O., Onunkwo, D. N., \& Herbert, U., (2017). Effects of garlic (Allium sativum) and vitamin $\mathrm{E}$ on blood profile, growth performance and internal organ characteristics of rabbit bucks. Nigerian Journal of Animal Production, 44(4), 167-176.

Amaduruonye, W., Ikwunze, K., Oguike, M. A., \& Onunkwo, D. N. (2018). Influence of ginger (Zingiber officinale) on histology, blood profile and internal organ characteristics of broilers. Nigerian Journal of Animal Science, 20(1), 61-71.

Bain, B. J., Lewis, S. M., \& Bates, I., (2006). Basic Hematological Techniques. In: Lewis, S. M., Bain, B. J., \& Bates, I. (eds.). Dacie and Lewis Practical Hematology, 10th Edition, Churchill Livingstone Elsevier, Philadelphia. Pp. 26-54.

Barratt, C. L. (2007). Semen analysis is the cornerstone of investigation for male infertility. The Practitioner, 8.

Baykan, Z., Öztürk, A., Poyrazoğlu, S., \& Gün, İ. (2011). Awareness, knowledge, and use of folic acid among women: a study from Turkey. Archives of gynecology and obstetrics, 283(6), 1249-1253.

Björndahl, L. (2010). The usefulness and significance of assessing rapidly progressive spermatozoa. Asian Journal of Andrology, 12(1), 33-35.

Brazil, C. (2010). Practical semen analysis: from A to Z. Asian journal of andrology, 12(1), 14-20.

Brugh, V. M., \& Lipshultz, L. I. (2004). Male factor infertility: evaluation and management. The Medical Clinics of North America, 88(2), 367-385.

Butt, F., \& Akram, N. (2013). Semen analysis parameters: Experiences and insight into male infertility at a tertiary care hospital in Punjab. Journal of Pakistan Medical Association, 63(5), 558-62.

Chibundu, U. C. (2005). Response of pre-pubertal bucks to administration of estradiol $\beta$. Project Report, Federal University of Technology, Owerri. p. 30.

Coll, O., Pisa, S., Palacio, M., Quintó, L., \& Cararach, V. (2004). Awareness of the use of folic acid to prevent neural tube defects in a Mediterranean area. European Journal of Obstetrics \& Gynecology and Reproductive Biology, 115(2), 173-177.

Cross, J. A., Cole, B. J., \& Spatny, K. P., (2015). Leukocytereduced platelet-rich plasma normalizes matrix metabolism in torn human rotator cuff tendons," American Journal of Sports Medicine, 43(12), 2898-2906.

Czeizel, A. E., (2000). Primary prevention of neural tube defects and some other major congenital abnormalities: recommendations for the appropriate use of folic acid during pregnancy. Paediatric Drugs, 2: 437-449.

Debowska, R. M., Rogiswicz, K., Iwanenko, T., \& Kruszewski, M., (2005). Folic acid (folacin) - New application of a cosmetic ingredient. Kosmetische Medizin, 26(3), 123-129.

Duncan, D. B. (1955). Multiple range and multiple $F$ tests. Biometrics, 11(1), 1-42.

Ekuma, B. O., Amaduruonye, W., Onunkwo, D. N., \& Herbert, U. (2017). Influence of garlic (Allium sativum) and vitamin $\mathrm{E}$ on semen characteristics, reproductive performance and histopathology of rabbit bucks. Nigerian Journal of Animal Production, 44(3), 117-128.

Feldman, B. F., Zinkl, J. G., \& Jain, N. C. (2000). Schalms veterinary hematology, 5th edition. Philadelphia, Williams and 
Wilkins. Pp. 21-100.

Fisch, H. (2008). Declining worldwide sperm counts: disproving a myth. Urologic Clinics of North America, 35(2), 137-146.

Foster, D. A., Wills, G., Denning, A., \& Bolger, M. (2009). The use of folic acid and other vitamins before and during pregnancy in a group of women in Melbourne, Australia. Midwifery, 25(2), 134-146.

Frandson, R. D., Lee, W. W., \& Anna, D. F. (2000). Blood and Other Body Fluids. In: Anatomy and physiology of farm animals, 7th edition, Wiley Blackwell publishers. Pp. 257-266.

Harris, I. D., Fronczak, C., Roth, L., \& Meacham, R. B. (2011). Fertility and the aging male. Reviews in urology, 13(4), e184.

Harvey, R. A., \& Ferrier, D. R., (2011). Fructose metabolism. Biochemistry (5th edition). Philadelphia:wolters Kluwer Health/Lippin Coh Williams \& Wilkins. Pp. 83-137.

Herbert, U., \& Acha, C. O. (1995). Preliminary observations on the seminal characteristics of rabbits raised in two locations in southeastern Nigeria. Nigerian Journal of Animal Production, 22(1), 108-112.

Herbert, U., \& Adejumo, D. O. (1995). Construction and evaluation of Artificial Vagina for collecting rabbit semen. Delta Agric, 2, 99-108.

Hodgetts, V. A., Morris, R. K., Francis, A., Gardosi, J., \& Ismail, K. M. (2015). Effectiveness of folic acid supplementation in pregnancy on reducing the risk of small-for-gestational age neonates: a population study, systematic review and metaanalysis. BJOG: An International Journal of Obstetrics and Gynaecology, 122(4), 478-490.

Jenkins, J. R. (2006). Clinical pathology- Normal values. BSAVA manual of rabbit medicine and surgery, 2nd edition, Pp. 45-51.

Jequier, A. M. (2010). Semen analysis: a new manual and its application to the understanding of semen and its pathology. Asian Journal of Andrology, 12(1), 11-13.

Josh, R., Adhikari, S., Patro, B. S., Chattopadhyay, S., \& Mukherjee, T. (2001). Free radical scavenging behavior of folic acid: Evidence for possible antioxidant activity. Journal of Free Radical Biology and Medicine, 30(12), 1390-1399.

Kahn, C. M., Line, S. \& Merck, C., (2010). The Merck veterinary manual. Whitehouse Station, N.J: Merck \&Co.

King, W., Toler, K., \& Woodell-May, J. (2018). Role of white blood cells in blood-and bone marrow-based autologous therapies. BioMed Research International, Volume 2018, Article ID 6510842.

Leineweber, C., Müller, E., \& Marschang, R. E. (2018). Blood reference intervals for rabbits (Oryctolagus cuniculus) from routine diagnostic samples. Tierärztliche Praxis Ausgabe K: Kleintiere/Heimtiere, 46(06), 393-398.

Lotti, F., \& Maggi, M. (2015). Ultrasound of the male genital tract in relation to male reproductive health. Human Reproduction Update, 21(1), 56-83.

McCarrel, T. M., Minas, T., \& Fortier, L. A. (2012). Optimization of leukocyte concentration in platelet-rich plasma for the treatment of tendinopathy. Journal of Bone and Joint Surgery, 94(19), e143.1-e143.8.

Meri, S. L., and Anu, S., (2017). Formation and function of sperm tail structure in association with sperm motility defects. Biology of Reproduction, 97(4), 522-536.

Misro, M. M., \& Ramya, T., (2012). Fuel/Energy sources of spermatozoa. In: Parekattil, S., \& Agarwal, A. (eds.). Male Infertility. Springer, New York, NY.

Molina, R. I., Martini, A. C., Tissera, A., Olmedo, J., Senestrari, D., de Cuneo, M. F., \& Ruiz, R. D. (2010). Semen quality and aging: analysis of 9.168 samples in Cordoba. Argentina. Archivos Espanoles de Urologia, 63(3), 214-22.

Moore, D. M., Zimmerman, K., \& Smith, S. A. (2015). Hematological assessment in pet rabbits: blood sample collection and blood cell identification. Veterinary Clinics: Exotic Animal Practice, 18(1), 9-19.

Morin, P., De Wals, P., St-Cyr-Tribble, D., Niyonsenga, T., \& Payette, H. (2002). Pregnancy planning: a determinant of folic acid supplements use for the primary prevention of neural tube defects. Canadian Journal of Public Health, 93(4), 259-263.

Mukhopadhyay, D., Varghese, A. C., Pal, M., Banerjee, S. K., Bhattacharyya, A. K., Sharma, R. K., \& Agarwal, A. (2010). Semen quality and age-specific changes: a study between two decades on 3,729 male partners of couples with normal sperm count and attending an andrology laboratory for infertilityrelated problems in an Indian city. Fertility and Sterility, 93(7), 2247-2254.

Naina, K., \& Singh, A. K., (2015). Trends of male factor infertility, an important cause of infertility: A review of literature. Journal of Human Reproductive Sciences, 8(4), 191-196.

Nawapun, K., \& Phupong, V. (2007). Awareness of the benefits of folic acid and prevalence of the use of folic acid supplements to prevent neural tube defects among Thai women. Archives of Gynecology and Obstetrics, 276(1), 53-57.

NRCRI (2004). Agro-meteorological Unit, National Root Crop Research Institute, Umudike, Umuahia, Nigeria.

Oguike, M. A., Onuta, S. C., Amaduruonye, W., \& Akpan, I. U. (2019). Impact of Aspilia africana on Semen and Testicular Characteristics of Rabbit Bucks. Journal of Advanced Agricultural Technologies, 6(2), 144 -149.

Onunkwo, D. N., Amaduruonye, W., Nathaniel, J., Ezike, J. C., \& Daniel-Igwe, G., (2018). Haematological and serum biochemical indices of broiler chickens fed Roselle seed meal (Hibiscus sabdariffa I.) as replacement for groundnut cake. Nigerian Journal of Animal Production, 45(4), 196-202.

Putwain, S. (2008). Clinical pathology update: hematology and biochemistry of the rabbit. Clinical Pathology of Lagomorph, 13(6), 75-77.

Riboh, J. C., Saltzman, B. M., Yanke, A. B., Fortier L., \& Cole, B. J. (2016). Effect of leukocyte concentration on the efficacy of platelet- rich plasma in the treatment of knee osteoarthritis. American Journal of Sports Medicine, 44(3), 792-800.

Sabra, S. M., \& Al-Harbi, M. S. (2014). An influential relationship of seminal fluid microbial infections and infertility, Taif Region, KSA. World Journal of Medical Sciences, 10(1), 32-37.

Steel, R. D. \& Torie, J. H. (1980). Principles and proceedings of statistics. A Biochemical Approach, 2nd edition, New York. USA: McGraw-Hill Book co. Inc.

Sun, S. Z., \& Empie, M. W. (2012). Fructose metabolism in humans-what isotopic tracer studies tell us. Nutrition \& metabolism, 9, Article number 89.

Toragall, M. M., Satapathy, S. K., Kadadevaru, G. G., \& Hiremath, M. B. (2019). Evaluation of seminal fructose and citric acid levels in men with fertility problem. Journal of Human Reproductive Sciences, 12(3), 199-203.

Uchewa, E. N., Amaduruonye, W., Onunkwo, D. N. \& Njoku, H. A. (2018). Performance of broiler chickens fed bush marigold (Aspilia africana) leaf extract. Nigerian Journal of Animal Science, 20(3), 223-228.

Unusan, N. (2004). Assessment of Turkish women's knowledge concerning folic acid and prevention of birth defects. Public Health Nutrition, 7(7), 851-855. 